\title{
Internet Activities During Leisure: A Comparison Between Adolescents With ADHD and Adolescents From the General Population
}

Vedrana Bolic Baric, Kristina Hellberg, Anette Kjellberg and Helena Hemmingsson

\author{
Linköping University Post Print
}

\section{Tweet}

N.B.: When citing this work, cite the original article.

Original Publication:

Vedrana Bolic Baric, Kristina Hellberg, Anette Kjellberg and Helena Hemmingsson, Internet Activities During Leisure: A Comparison Between Adolescents With ADHD and Adolescents From the General Population, 2015, Journal of Attention Disorders.

$\underline{\text { http://dx.doi.org/10.1177/1087054715613436 }}$

Copyright: SAGE Publications (UK and US)

http://www.uk.sagepub.com/home.nav

Postprint available at: Linköping University Electronic Press

http://urn.kb.se/resolve?urn=urn:nbn:se:liu:diva-123871 
Internet activities during leisure -a comparison between adolescents with ADHD and adolescents from the general population

Authors:

Vedrana Bolic Baric, Department of Social and Welfare Studies, Linköping University, Norrköping, Sweden

Kristina Hellberg, Department of Pedagogy, Linnaeus University, Växjö, Sweden Anette Kjellberg, Department of Social and Welfare Studies, Linköping University, Norrköping, Sweden

Helena Hemmingsson, Department of Social and Welfare Studies, Linköping University, Norrköping, Sweden

\section{Corresponding author:}

Vedrana Bolic baric, Department of Social and Welfare Studies, Linköping University, Norrköping, Sweden, SE-601 74 Norrköping, Telephone: + 4611 363504, Fax: + 4611 363189, Email: vedrana.bolic@liu.se 


\begin{abstract}
Adolescents' leisure activities are increasingly focusing on Internet activities and today, these co-exist with traditional leisure activities such as sport and meeting friends. Objective: To investigate leisure activities, particularly Internet activities, among boys and girls with attention deficit/hyperactivity disorder (ADHD), and compare these to boys and girls from the general population. The objective was also to explore how traditional leisure activities and Internet activities interrelate among adolescents with ADHD. Method: Adolescents with ADHD $(n=102)$ were compared to adolescents from the general population on leisure activities and Internet use. Results: Leisure activities among adolescents with ADHD tended to focus on Internet activities, particularly online games. Internet activities were broadening leisure activities among adolescents with ADHD, rather than being a substitute for traditional leisure activities. Conclusion: There is a need to discuss how Internet activities might provide adolescents with ADHD with accessible means of social interaction where individuals can interact with others.
\end{abstract}




\section{Introduction}

For adolescents, participation in everyday activities is considered an essential part of human development (Law, 2002), and leisure activities is one important aspect of health and wellbeing (Law, Petrenchik, Ziviani, \& King, 2006). Leisure activities can provide adolescents with an opportunity to develop skills and competencies, increased physical and psychological development, and a sense of belonging. Through leisure activities, adolescents can also express their personal identity and find meaning and purpose in life (Law, 2002; King et al., 2003). However, despite the suggested importance of leisure in adolescents' lives, participation in leisure activities appears far from straightforward for adolescents with attention deficit hyperactivity disorder (ADHD). Research has shown that adolescents with ADHD may experience sensory, motor, and behavioral difficulties (Baerg et al., 2011; Johnson \& Rosén, 2000; Lin, Yang, \& Su, 2013; Engel-Yeger \& Ziv-On, 2011), as well as physical and social barriers to leisure participation (Thomson \& Emira, 2011). Social difficulties with peer relationships, including lack of friendships are experienced by children and adolescents with ADHD. Children and adolescents with ADHD may experience difficulties to follow rules, paying attention during activities, and a tendency to show disruptive and aggressive behaviors (Hoza, 2007; McQuade \& Hoza, 2008). In the present study, leisure is defined as the activities performed during the informants' free time outside of school. It includes activities of choice as well as obligations, such as homework and household tasks (Primeau, 1996; Suto, 1998). In line with Bryce (2001), leisure is in the current study considered as consisting of a wide scope of activities, for instance, traditional leisure activities such as sport, playing an instrument, meeting friends, and various Internet 
activities, such as online gaming and surfing. In the last 10 years, Internet activities have become an important source for leisure due to high-speed Internet access, new technology applications, and the recent possibility to use the Internet on mobile devices (Findahl, 2014; Rideout, Foehr, \& Roberts, 2010; Yelland, 2013). To date, research on adolescents with ADHD has mainly focused on the potential risk of Internet activities, including the increased risk of problems in connection with online gaming and Internet addiction (Carli et al., 2012, Chou, Liu, Yang, Yen, \& Hu, 2015; Weiss, Baer, Allan, Saran, \& Schibuk, 2011; Yen, Yen, Chen, Tang, \& Ko, 2009). Concerns have also been raised about the detrimental impact of increased online gaming on grades at school (Chan \& Rabinowitz, 2006), and reduced sleep (Engelhardt, Mazurek, \& Sohl, 2013) among adolescents with ADHD. However, research has also shown that Internet activities enable adolescents with cognitive disabilities to establish social contacts by enhancing existing relationships and reducing loneliness (Blanck, 2014; Shaw \& Gant, 2002).

The above mentioned studies have focused on investigating specific Internet activities that adolescents with ADHD perform, such as playing online games. Knowledge about how adolescents with ADHD perform a variety of leisure activities, including traditional leisure activities (e.g., sports, meeting friends), as well as various Internet activities (e.g., online gaming, searching for information, chatting) is still scarce. To our knowledge, earlier studies focusing on comparing a variety of leisure activities performed by children with ADHD to those performed by peers from the general population, have mainly included specific Internet activities, such as playing computer games (Engel-Yeger \& Ziv-On, 2011; Shimoni, Engel-Yeger, \& Tirosh, 2010). For example, Engel-Yeger and Ziv-On (2011) investigating preferences for participation in a variety of leisure activities, showed that children with ADHD may experience sensory processing difficulties that negatively influence 
their preference to participate in social activities. Similarly, Shimoni et al. (2010) investigated actual participation in a variety of formal and informal leisure activities among children with ADHD. The results showed that children with ADHD tended to be less engaged in social activities and skill-based activities (e.g., sports, dancing), but that participation in physical (e.g,. riding a bicycle, playing catch) and recreational activities (e.g., playground, computer games) was similar to their typical peers. However, these studies were conducted in younger children (age <13) and included only boys with ADHD (Engel-Yeger \& Ziv-On, 2011; Shimoni et al., 2010). The current study adds to this knowledge by investigating differences and similarities in a variety of leisure activities, including traditional leisure activities and various Internet activities, among both boys and girls with ADHD in the older age groups, and boys and girls in the general population. Therefore, the objective of the present study was to investigate leisure activities, particularly Internet activities, among boys and girls with attention deficit/hyperactivity disorder (ADHD), compared to those of boys and girls from the general population. The objective was also to explore how traditional leisure activities and Internet activities interrelate among adolescents with ADHD.

\section{Method}

This cross-sectional questionnaire study is part of a larger project investigating information and communication technology (ICT) during leisure by adolescents with various disabilities, including ADHD. Results on ICT use by adolescents with physical disabilities at school and during leisure, and ICT use by adolescents with ADHD at school have been published elsewhere (Bolic, Lidström, Thelin, Kjellberg, \& Hemmingsson, 2013; Lidstöm, 2011; Lidström, Ahlsten, \& Hemmingsson, 2010; Lidström, Granlund, \& Hemmingsson, 2012). 
Ethical approval for this study was granted by the Regional Ethical Review Board (2006/1101-31).

\section{Participants}

Adolescents with ADHD were recruited from registers at Habilitation centers (HC) in Central Sweden. HC's are a part of the public health service responsible for providing interdisciplinary support (e.g paediatrics, occupational therpy, physical therapy) to children and adolescents with disabilities and their families. The HC's identified participants with a primary diagnosis of ADHD from their medical records based on the following inclusion criteria: adolescents with a primary diagnosis of ADHD, aged between 12 and 18 years $(\mathrm{n}=102)$. Data were not available concerning medication and co-morbidity. Details of recruitment and response rate for adolescents with ADHD in this project have been previously published by Bolic, Lidström, Thelin, Kjellberg, and Hemmingsson (2013). Analysis of response bias regarding age and sex has been reported earlier (Bolic, Lidström, Thelin, Kjellberg, \& Hemmingsson, 2013), and demonstrated no significant differences between the participants in the present study and non-respondents $(p>0.05)$.

\section{Reference group}

Group comparisons were made between adolescents with ADHD and adolescents from the general population aged 12-16 years $(n=677)$. The group comprised of 342 boys and 335 girls, recruited from the national survey "Kids and Media" about children's and adolescents' leisure and ICT use, and conducted by the Swedish media Council (The Swedish Media Council, 
Internet activities during leisure

2006). The age span differed slightly for adolescents with ADHD and adolescents in the reference group (12-16 years of age). As the present study aimed at including adolescents in the higher age groups, participants with ADHD up to 18 years of age were included. Withingroup analyses of leisure activities among adolescents with ADHD aged 17-18 years and younger participants aged 12-16 years revealed no significant differences with regard to the included questions.

\section{Questionnaire}

Data was collected using a questionnaire on leisure activities and ICT use by children with disabilities such as ADHD, developed and described earlier by Lidström and colleagues (Lidström, 2011). In order to enable a comparison with adolescents from the general population, 9 of the 15 questions in the questionnaire were replicated from the national survey "Kids and Media" (The Swedish Media Council, 2006). The results of the current study were based on questions focusing on leisure activities, Internet activities, and participants' characteristics. Examples of the replicated questions were as follows: "What do you usually do in your leisure?", with 14 different activities to tick yes/no. This question was not found in the national survey "Kids and Media" from 2006 and data $(n=713)$ from the year before were used with respect to that question (The Swedish Media Council, 2005). Other examples of the replicated questions were: “What do you usually do on the Internet in your leisure?”, where the participants could tick 5 out of 10 activities (e.g., playing online games, chatting, surfing). The questionnaire also included questions specifically constructed for adolescents with disabilities, for example; "How satisfied are you with your computer use in leisure activities?". The participants graded their satisfaction on a 5-point Likert scale, where $1=$ not satisfied at all and $5=$ very satisfied. Reliability for the questions about traditional leisure 
activities and Internet activities in terms of internal consistency for adolescents with ADHD was calculated. The Cronbach alpha value of $\alpha=0.67$ for the present study are close to the generally accepted value of 0.7 , indicating an acceptable average correlation between items (Field, 2013).

\section{Statistical methods}

Differences between the groups were analyzed using a chi-squared test with the statistically significant level set at $\mathrm{p}<0.05$. Where cell size was below five, Fisher's exact test was used (Polit \& Beck, 2008). Statistical analyses were carried out using SPSS Statistics 22.

A principal component analysis (PCA) with orthogonal rotation (varimax) was performed in the present study in order to explore related activities that adolescents with ADHD perform in their leisure and on the Internet. The analysis was based on the two questions: "What do you usually do in your leisure?" with 14 activities to choose from and “What do you usually do on the Internet in your leisure?” with 10 Internet activities to choose from. Two redundant items (surfing the Internet and playing computer games) from Table I were excluded from the analysis as they did not differentiate between, for example, time spent on the Internet in general and specific activities. This resulted in 22 activities being included in the analysis. The Keyser-Meyer-Olkin measure $(\mathrm{KMO})=.54$ is within the accepted value of 0.5 , which supports sampling adequacy (Field, 2013). An initial analysis was performed to obtain eigenvalues for each factor in the data. Only the factors with eigenvalues of 1.0 were retained for the final rotation. Eight factors had eigenvalues over Kaiser's criterion of 1 and together explained $66 \%$ of the total variance (Field, 2013). A minimum loading of 0.40 was used for the inclusion of a leisure activity on a particular factor (Field, 2013). Each factor was interpreted and named. The resulting factors and their related 
activities are presented in Table III in the results section. The factors were further grouped together based on types of leisure activities; (I) a mix of Internet activities and traditional leisure activities for entertainment and information acquisition, (II) Internet activities for interaction with others, and (III) traditional activities for cultural activities and homework.

\section{Results}

\section{Characteristics of the participants}

The participants with ADHD consisted of 81 boys $(79 \%)$ and $21(21 \%)$ girls $(\mathrm{p}<0.05)$. Mean age was 14 years and 2 months (SD 1 years and 7 months). There were significantly more boys with ADHD than in the reference group $342(51 \%)(p<.001)$. Fifty-seven per cent of the participants lived in a rural area. Access to a computer (97\%) and Internet (94\%) was high among adolescents with ADHD, which is in accordance with the available statistics on the general population $(92 \%)$ (Findahl, 2014). About half of the adolescents with ADHD stated that they had access to a computer that was shared by the family (53\%), and $42 \%$ reported having access to an own computer at home. Seventeen per cent of the participants stated that they used an input device for the computer, including alternative access solutions and specific software. No comparison data is available for adolescents aged 12-16 years specifically, concerning residential area, access to computers and using input devices. No gender differences were evident between boys and girls with ADHD concerning the above mentioned questions.

\section{Opinions about computer use during leisure.}

Adolescents with ADHD stated that they were either fairly satisfied (42\%) or very satisfied $(41 \%)$ with their computer use in their leisure. Nevertheless, almost half (46\%) of them stated 
that they would like to use the computer more often and for more leisure activities. No comparison data is available concerning satisfaction with computer use in leisure for the reference group. Almost all of the adolescents with ADHD consider online/video games (95 $\%$ vs. $82 \%)$ to be fun to use ( $\mathrm{p}>0.05)$, and significantly more adolescents with ADHD consider online/video games to be a social activity in which they can socialize with friends $(75 \%$ vs. $53 \%)(\mathrm{p}<0.05)$. Additionally, significantly more adolescents with ADHD consider online/video games (91\% vs. 58\%) to provide learning experiences $(\mathrm{p}<0.05)$. Forty five percent of adolescents with ADHD stated having parents setting rules at home for using the computer, with no differences with adolescents from the reference group (41\%). There were no differences concerning choosing to play computer games alone between adolescents with ADHD (62\%) and adolescents from the reference group (67\%) $(p>0.05)$.

\section{Leisure activities}

Comparison of leisure activities between adolescents with ADHD and adolescents from the reference group revealed significant differences in 7 out of 14 leisure activities, see Table 1 . The analysis revealed that a significantly lower proportion of adolescents with ADHD performed activities such as meeting friends, doing homework, doing sports ( $p<.001)$, reading books/newspapers, and acting/dancing $(p<.05)$ compared to adolescents from the reference group. On the other hand, a higher proportion of adolescents with ADHD played computer games and videogames more frequently than adolescents from the reference group.

When comparing boys and girls with ADHD separately, the analysis revealed that a higher proportion of girls with ADHD played computer games than girls from the reference group, while there were no differences between boys with ADHD and boys from the reference group $(\mathrm{p}<0.05)$. On the other hand, the analysis revealed that a lower proportion of 
boys with ADHD performed activities such as doing sport, compared to boys from the reference group.

>> Insert Table I about here $<<$

\section{Internet activities during leisure}

As presented in Table 2, a comparison of Internet activities between adolescents with ADHD and adolescents from the reference group demonstrated that a higher proportion of adolescents with ADHD used the Internet for playing games online, visiting communities, and looking at pornography, compared to adolescents from the reference group $(\mathrm{p}<0.05)$. In contrast, adolescents with ADHD used the Internet less frequently for chatting and doing homework, compared to the reference group $(\mathrm{p}<0.05)$.

As presented in Table 2, a comparison between boys with ADHD and boys from the reference group demonstrated that boys with ADHD chatted to a lower extent than boys from the reference group, while a higher proportion visited communities online $(\mathrm{p}<0.05)$. There were no differences between girls with ADHD and girls from the reference group.

$$
\text { >> Insert Table II about here }<<
$$

\section{Different clusters of leisure activities performed by adolescents with ADHD}

The application of PCA to identify correlated leisure activities and Internet activities among adolescents with ADHD produced eight factors, as presented in Table 3. These factors together represented three types of related leisure activities: (I) a mix of Internet activities and traditional leisure activities for entertainment and information acquisition, (II) Internet 
activities for interaction with others, and (III) traditional activities for cultural activities and homework. The first type of related leisure activities (a mix of Internet activities and traditional leisure activities) showed that some leisure activities were performed both on the Internet and offline (factors one, six, and eight), including using the Internet for information acquisition and entertainment without abandoning traditional means for doing the same activities. For example, the first factor showed that Internet activities related to accessing digital information (e.g., surfing the Internet), are related to traditional means for informational purposes, such as reading books/newspapers. The second type of leisure activities (factors three and seven) showed that the Internet was used for interaction and communication with others through communities, chats, and e-mail. The third type of leisure activities (factors two, four, and five), showed that particularly creative activities, such as crafts/drawing, taking care of animals, and acting/dancing were performed without using the Internet.

> Insert Table III about here $<<$

\section{Discussion}

The present study applies a broad perspective on leisure activities. It provides new insight into several leisure activities, including a variety of specific Internet activities that characterize leisure among boys and girls with ADHD, compared to adolescents from the general population. The findings indicate that in comparison with adolescents from the general population, adolescents with ADHD were less frequently involved in a variety of leisure activities. These included meeting with friends, sports, and acting/dancing, and were considered as representing traditional forms of leisure activities (Bryce, 2001). In contrast to the activities mentioned above, leisure activities among adolescents with ADHD focused 
more on Internet activities, such as playing computer games, compared to adolescents from the general population. There are several potential explanations for why individuals with ADHD prefer Internet activities more than traditional leisure activities. Sonuga-Barke (2002) suggested that individuals with ADHD may exhibit poor inhibitory response and poor executive functioning which causes problems with task engagement. In addition, individuals with ADHD prefer immediate rewards which may be influenced by their motivational style (Sonuga-Barke, 2002). It has been suggested that the audiovisual and structural features of video games (e.g. sound effects, flickering light levels), provide motivation and excitement which may facilitate better inhibitory performance for individuals with ADHD ((Bioulac et al., 2014; Gentile, Swing, Lim, \& Khoo, 2012). Moreover, a tendency for stimulation seeking in individuals with ADHD has been suggested (Antrop et al., 2000). Computer games are considered to provide immediate feedback, multimodal and high stimulation, while putting minimal demands on attention (Weiss et al, 2011). This may explain why individuals with ADHD prefer to play computer games and spend a considerable time playing computer games (Gentile et al., 2012). Earlier research focusing on investigating leisure activities in individuals with ADHD is based primarily on results obtained from research on young boys (Engel-Yeger \& Ziv-On, 2011; Shimoni et al., 2010). The present study found that a higher proportion of girls with ADHD played computer games, compared to girls from the reference group, while there were no differences between boys with ADHD and boys from the reference group. Despite the fact that there were only a small number of girls in the present study $(\mathrm{n}=$ 21), the initial findings on the leisure activities of girls with ADHD contribute to the interest in research on girls with ADHD during the last decade (Kopp, 2010). More research with a sufficient number of girls is needed before conclusions can be drawn about leisure activities among girls with ADHD. 
The findings revealed that adolescents with ADHD were likely to use the Internet for entertainment (e.g., playing online games) and social networking through communities and chat rooms. These findings are consistent with conclusions drawn from other studies focusing on Internet use among adolescents from the general population in Sweden and other European countries. Young people's engagement with the Internet focuses primarily on games and communication (Findahl, 2014; Livingstone, Haddon, Görzig, \& Ólafsson, 2011). Concerns have been raised by parents and professionals about how online gaming and online interaction during leisure might reduce social interactions with the family and peers. For adolescents with ADHD in particular, concerns also focus on problematic use of online gaming and Internet addiction (Carli et al., 2012; Chou et al., 2015; Weiss et al., 2011; Yen et al., 2009). On the other hand, research has also shown that Internet activities providing online communication may facilitate new and existing relationships (Schreuer, 2014), provide a gateway to greater computer confidence, and lay the ground for knowledge and digital skills acquisition at school, which is required for participation in contemporary society (Cox, 2013; Gentile, 2011; Voogt, Knezek, Cox, Knezek, \& ten Brummelhuis, 2011). Controversy concerning online and face-to-face interactions exists as a consequence of contradictory findings, and there has been a call for studies focusing on how Internet use relates to other leisure activities (Subrahmanyan, Greenfield, Krautc, \& Gross, 2001). The current study goes beyond previous studies on leisure activities among boys with ADHD focusing on specific Internet activities, such as gaming (Engel-Yeger \& Ziv-On, 2011; Shimoni et al., 2010), by including a variety of Internet activities and distinguishing between how these and traditional leisure activities relate to each other among both boys and girls in the older age groups. Findings revealed, for instance, that the Internet is primarily used for entertainment and communication purposes, in contrast to creative activities (e.g., 
crafts/drawing, acting/dancing), and homework, which are performed offline. Specifically, the first type of related leisure activities, that is, a mix of Internet activities and traditional leisure activities for entertainment and information acquisition, indicated that Internet activities may serve primarily as a broadening of adolescents' leisure activities, rather than as a replacement of traditional leisure activities. For example, the factor analysis revealed that using the Internet to access online information relates to using traditional means for informational purposes, such as reading books/newspapers. This finding shows that adolescents with ADHD who used the Internet for gathering information still used traditional sources for searching information in newspapers. Such complementary relationships between using the Internet for gathering information and reading newspapers have been established by previous research in the general population (Dutta-Bergman, 2004; Nguyen \& Western, 2006). Moreover, the second type of leisure activities (Internet activities for interaction with others) suggested that Internet activities may provide adolescents with ADHD with accessible means of social interaction, where they can socialize and communicate with others through communities, chat rooms and email, as shown in factor three. Factor seven particularly showed that downloading music was related to chatting with peers. Based on these results, it is suggested that Internet activities provide opportunities for establishing communication with friends, which may be complimentary to traditional means of meeting face-to- face. These findings are in line with earlier research describing Internet based social interactions as inherently interactive. This means that adolescents can easily connect with a wide network of individuals, including preexisting friends, and establish new friendships (Livingston \& Brake, 2010). In particular, earlier research (Cardon \& Granjon, 2005) has suggested that music may provide a topic for conversation with others in chat rooms, and thus provide new important contexts for meeting with friends that go beyond face-to- face meetings. Taken together, by distinguishing between 
specific Internet activities, the current study shows that adolescents with ADHD may use the Internet for communication and information acquisition which enhances and/or complements their leisure activities. The findings add to the discussion regarding the potential risk or advantage of Internet activities in the lives of adolescents with ADHD by showing that specific Internet activities may complement and provide additional opportunities for gathering information and social interaction with peers, and that all Internet activities should not be treated as potentially harmful. Virtual reality (VR) such as exergaming using dynamic body activity as the input for interacting with computer games has been suggested as a means to increase exercise and provide alternative to traditional sport activities among adolescents without disabilities (Douris, McDonald, Vespi, Kelley, \& Herman, 2012). A significant body of research has suggested that cognitive training provided through computer games may be a promising tool to increase attention and decrease hyperactivity and impulsivity of individuals with ADHD (Mishra et al., 2013; Moriyama et al., 2012). Cognitive training may positively influence the performance of traditional leisure activities such as doing sports and meeting friends. However, this needs to be considered in further research studies.

The third type of leisure activities (factors two, four, and five), shows that particularly creative activities, such as crafts/drawing, taking care of animals, and acting/dancing were performed without using the Internet. Only one fifth of the adolescents with ADHD stated that they used the Internet for homework, and even less for more elaborate tasks, such as creating texts and pictures, despite ready access to both computers and the Internet. This finding is in line with research on Internet activities in adolescents in the general population, showing that Internet activities among adolescents are narrow in range. Although young people may know how to find and extract basic information online, they may lack the critical literacy needed for understanding and criticizing information and perform 
more elaborated tasks, such as filling in electronic job applications and creating webpages (Vandebosch, 2011). Earlier research by Bolic et al. (2013) found that young people with ADHD use the computer less for educational purposes at school (e.g., searching for information on the Internet, making presentations, and e-mailing teachers), compared to adolescents with or without physical disabilities. Taken together, the limited use of a computer for specific educational purposes in the classroom, and the focus on using the Internet for games and communication during leisure among adolescents with ADHD, is in line with Vandebosch (2011), indicating that Internet activities may not be fully explored as a resource for homework or specific educational activities in this group. This highlights the need for initiative by parents and professionals to support adolescents with ADHD in exploring a wider uptake of Internet activities in a creative and safe way at home for school work and in the formal educational setting. These wider digital skills are required in preparing adolescents with ADHD for the transition to higher education, labor market and contemporary society.

\section{Limitations}

This study has several limitations. The cross-sectional comparison of leisure activities among adolescents with ADHD and adolescents from the general population does not allow for cause-effect relationships to be established. Therefore, it is not possible to say whether playing games led to less performance of other leisure activities, or if adolescents were playing games because other leisure activities were inaccessible. However, it does provide an important and novel comparison of a variety of leisure activities, including specific Internet activities and traditional leisure activities (e.g., sports), between adolescents with ADHD and adolescents from the reference group, as it is common for adolescents with ADHD to perform a wide variety of these activities (Weiss et al., 2011). Lack of data concerning comorbidity is 
a limitation, since it is shown that individuals with ADHD with comorbidity such as anxiety and depression may represent a risk factor for Internet addiction (Yen, Chou, Liu, Yang, \& $\mathrm{Hu}, 2014)$. In addition, internet activities such as online gaming have been reported as being significantly associated with severe Internet addiction in adolescents with ADHD (Chou et al., 2015).

The available data on the reference group resulted in limited comparison between the groups. Nevertheless, it enabled crucial comparison between the groups between a variety of traditional leisure activities and specific Internet activities. With the rapid development of Internet technology, cell phones in particular, there is an urgent need for further research in this area.

\section{Conclusion}

Compared to traditional leisure activities such as sports and acting/dancing, Internet activities, particularly online and video games, appear to take up a crucial part of leisure in adolescents with ADHD. Internet activities serve primarily as a broadening of their leisure activities, rather than as a substitute for traditional leisure activities. The current study shows that Internet activities, especially social communities and downloading music, might provide adolescents with ADHD with accessible means of social interaction, where individuals can interact with each other in physical and virtual spaces. Furthermore, the findings indicate that using the Internet to access online information may serve primarily as a complement to traditional means of gathering news and information among adolescents with ADHD. 
Table I. A comparison of leisure activities between boys and girls with ADHD and boys and girls from the reference group.

\begin{tabular}{|c|c|c|c|c|c|c|c|c|c|}
\hline & \multirow{2}{*}{$\begin{array}{l}\text { Adolescents } \\
\text { with ADHD } \\
(\mathrm{n}=102) \\
\mathrm{N}(\%)\end{array}$} & \multirow{2}{*}{$\begin{array}{l}\begin{array}{l}\text { Reference } \\
\text { group }\end{array} \\
(\mathrm{n}=713) \\
\mathrm{N}(\%)\end{array}$} & \multirow[t]{2}{*}{$p$} & \multicolumn{2}{|c|}{$\begin{array}{c}\text { (1) } \\
\text { Adolescents with } \\
\text { ADHD }\end{array}$} & \multicolumn{2}{|c|}{$\begin{array}{c}(2) \\
\text { Reference group }\end{array}$} & \multirow{2}{*}{$\begin{array}{l}\text { Significant } \\
\text { differences } \\
\text { between } 1 \text { (a) } \\
\text { and } 2 \text { (a) }\end{array}$} & \multirow{2}{*}{$\begin{array}{l}\text { Significant } \\
\text { differences } \\
\text { between } 1 \text { (b) } \\
\text { and } 2 \text { (b) }\end{array}$} \\
\hline & & & & $\begin{array}{l}\text { Boys } \\
81(79.4) \\
\quad \text { (a) }\end{array}$ & $\begin{array}{l}\text { Girls } \\
21(20.6) \\
\text { (b) }\end{array}$ & $\begin{array}{l}\text { Boys } \\
346(48.5) \\
\quad \text { (a) }\end{array}$ & $\begin{array}{l}\text { Girls } \\
367 \text { (51.5) } \\
\quad \text { (b) }\end{array}$ & & \\
\hline Watching TV/video/DVD & $83(81.4)$ & $538(75.5)$ & ns & $66(81.5)$ & $17(81.0)$ & $256(74.0)$ & $282(76.8)$ & ns & ns \\
\hline Meeting friends & $70(68.6)$ & $612(85.8)$ & $<.001 * *$ & $57(70.4)$ & $13(61.9)$ & $294(85.0)$ & $318(86.6)$ & $.002 *$ & $.002 *$ \\
\hline Surfing the Internet & $67(65.7)$ & $449(63.0)$ & ns & $52(64.2)$ & $15(71.4)$ & $211(61.0)$ & $238(64.9)$ & ns & ns \\
\hline Listening to music & $62(60.8)$ & $490(68.7)$ & ns & $49(60.5)$ & $13(61.9)$ & $215(62.1)$ & $275(74.9)$ & ns & ns \\
\hline Playing computer games & $63(61.8)$ & $302(42.4)$ & $<.001 * *$ & $52(64.2)$ & $11(52.4)$ & $225(65.0)$ & $77(21.0)$ & ns & $.002 *$ \\
\hline Doing homework & $55(53.9)$ & $556(78.0)$ & $<.001 * *$ & $41(50.6)$ & $14(66.7)$ & $249(72.0)$ & $307(83.7)$ & $<.001 * *$ & ns \\
\hline Playing video-games & $48(47.1)$ & $176(24.7)$ & $<.001 * *$ & $44(54.3)$ & $4(19.0)$ & $176(50.9)$ & $33(9.0)$ & ns & ns \\
\hline Doing sports & $35(34.3)$ & $455(63.8)$ & $<.001 * *$ & $23(28.4)$ & $12(57.1)$ & $232(67.1)$ & $223(60.8)$ & $<.001 * *$ & ns \\
\hline Doing household tasks & $32(31.4)$ & $268(37.6)$ & ns & $23(28.4)$ & $9(42.9)$ & $111(32.1)$ & $157(42.8)$ & ns & ns \\
\hline $\begin{array}{l}\text { Reading } \\
\text { books/newspapers }\end{array}$ & $32(31.4)$ & $325(45.6)$ & $.007 *$ & $24(29.6)$ & $8(38.1)$ & $131(37.9)$ & $194(52.9)$ & ns & ns \\
\hline Doing crafts/drawing & $23(22.5)$ & $130(18.2)$ & ns & $11(13.6)$ & $12(57.1)$ & $28(8.1)$ & $102(27.8)$ & ns & $.004 *$ \\
\hline Taking care of animals & $23(22.5)$ & $223(31.3)$ & ns & $15(18.5)$ & $8(38.1)$ & $73(21.1)$ & $150(40.9)$ & ns & ns \\
\hline Playing an instrument & $12(11.8)$ & $136(19.1)$ & ns & $9(11.1)$ & $3(14.3)$ & $66(19.1)$ & $70(19.1)$ & ns & ns \\
\hline Acting/dancing & $2(2.0)$ & $62(8.7)$ & $0.016^{*}$ & $0(0.0)$ & $2(9.5)$ & $7(2.0)$ & $55(15.0)$ & ns & ns \\
\hline
\end{tabular}

$p<0.05^{*}, p<0.01^{* *} \mathrm{~ns}=$ non-significant 
Table II. A comparison of Internet activities between boys and girls with ADHD and boys and girls from the reference group.

\begin{tabular}{|c|c|c|c|c|c|c|c|c|c|}
\hline & \multirow{2}{*}{$\begin{array}{l}\text { Adolescents } \\
\text { with ADHD } \\
(\mathrm{n}=102) \\
\mathrm{N}(\%)\end{array}$} & \multirow{2}{*}{$\begin{array}{l}\text { Reference } \\
\text { group } \\
(\mathrm{n}=677) \\
\mathrm{N}(\%)\end{array}$} & \multirow[t]{2}{*}{$p$} & \multicolumn{2}{|c|}{ Adolescents with ADHD } & \multicolumn{2}{|c|}{$\begin{array}{c}\text { (2) } \\
\text { Reference group }\end{array}$} & \multirow{2}{*}{$\begin{array}{l}\text { Significant } \\
\text { differences } \\
\text { between } 1 \text { (a) } \\
\text { and } 2 \text { (a) }\end{array}$} & \multirow{2}{*}{$\begin{array}{l}\text { Significant } \\
\text { differences } \\
\text { between } 1(\mathrm{~b}) \\
\text { and } 2 \text { (b) }\end{array}$} \\
\hline & & & & $\begin{array}{c}\text { Boys } \\
81(79.4) \\
\text { (a) }\end{array}$ & $\begin{array}{c}\text { Girls } \\
21(20.6) \\
\text { (b) }\end{array}$ & $\begin{array}{c}\text { Boys } \\
342(50.5) \\
\text { (a) }\end{array}$ & $\begin{array}{c}\text { Girls } \\
335(49.5) \\
\text { (b) }\end{array}$ & & \\
\hline Playing online games & $72(70.6)$ & $376(55.5)$ & $.004 *$ & $59(72.8)$ & $13(61.9)$ & $239(69.9)$ & $137(40.9)$ & ns & ns \\
\hline Chatting & $65(63.7)$ & $542(80.1)$ & $<.001 * *$ & $50(61.7)$ & $15(71.4)$ & $257(75.1)$ & $285(85.1)$ & $.015^{*}$ & ns \\
\hline Surfing the Internet & $53(52.0)$ & $305(45.1)$ & $\mathrm{ns}$ & $41(50.6)$ & $12(57.1)$ & $161(47.1)$ & $144(43.0)$ & ns & ns \\
\hline $\begin{array}{l}\text { Downloading } \\
\text { music/movies }\end{array}$ & $40(39.2)$ & $217(32.1)$ & ns & $34(42.0)$ & $6(28.6)$ & $140(40.9)$ & $77(23.0)$ & $\mathrm{ns}$ & ns \\
\hline Visiting communities & $39(38.2)$ & $118(17.4)$ & $<.001 * *$ & $31(38.3)$ & $8(38.1)$ & $48(14.0)$ & $70(20.9)$ & $<.001 * *$ & $\mathrm{~ns}$ \\
\hline $\begin{array}{l}\text { Searching for } \\
\text { information }\end{array}$ & $35(34.3)$ & $186(27.5)$ & ns & $26(32.1)$ & $9(42.9)$ & $82(24.0)$ & $104(31.0)$ & $\mathrm{ns}$ & $\mathrm{ns}$ \\
\hline E-mailing & $29(28.4)$ & $233(34.4)$ & $\mathrm{ns}$ & $18(22.2)$ & $11(52.3)$ & $92(26.9)$ & $141(42.1)$ & $\mathrm{ns}$ & ns \\
\hline Doing homework & $23(22.5)$ & $311(45.9)$ & $<.001 * *$ & $18(22.2)$ & $5(23.8)$ & $123(36.0)$ & $188(56.1)$ & $.018 *$ & $.004 *$ \\
\hline $\begin{array}{l}\text { Uploading texts and } \\
\text { pictures }\end{array}$ & $9(8.8)$ & $54(8.0)$ & ns & 7 (8.6) & $2(9.5)$ & $17(5.0)$ & $37(11.0)$ & ns & ns \\
\hline $\begin{array}{l}\text { Looking at } \\
\text { pornography }\end{array}$ & $6(5.9)$ & $13(1.9)$ & $.016^{*}$ & $5(6.2)$ & $1(4.8)$ & $10(2.9)$ & $3(0.9)$ & $\mathrm{ns}$ & $\mathrm{ns}$ \\
\hline
\end{tabular}

$p<0.05^{*}, p<0.01^{* *} \mathrm{~ns}=$ non-significant 
Table III. Resulting factors of leisure activities and Internet activities among adolescents with ADHD.

\begin{tabular}{|c|c|c|}
\hline Labeled factors & Leisure activities & Factor loading $^{\mathrm{a}}$ \\
\hline \multirow[t]{4}{*}{ (1) "Using the Internet for entertainment and reading books offline" } & Searching for information & 0,681 \\
\hline & Reading books/newspapers & 0,676 \\
\hline & Surfing the Internet & 0,676 \\
\hline & Playing online games & 0,492 \\
\hline \multirow[t]{3}{*}{ (2) "Music and meeting friends" } & Listening to music & 0,740 \\
\hline & Meeting friends & 0,668 \\
\hline & Using the Internet for doing homework & $-0,515$ \\
\hline \multirow[t]{3}{*}{ (3) "Social activities online" } & Visiting communities & 0,753 \\
\hline & Chatting & 0,679 \\
\hline & E-mailing & 0,663 \\
\hline \multirow[t]{3}{*}{ (4) "Creative activities" } & Doing crafts/drawing & 0,684 \\
\hline & Taking care of animals & 0,641 \\
\hline & Acting/dancing & 0,611 \\
\hline \multirow[t]{2}{*}{ (5) "Activities in the home" } & Doing household tasks & 0,746 \\
\hline & Doing homework & 0,623 \\
\hline \multirow[t]{3}{*}{ (6) "Cultural activities" } & Uploading text and pictures online & 0,756 \\
\hline & Watching TV/video/DVD & 0,498 \\
\hline & Acting/dancing & 0,493 \\
\hline \multirow[t]{2}{*}{ (7) "Downloading music and socializing" } & Downloading music/movies & 0,806 \\
\hline & Chatting & 0,426 \\
\hline \multirow[t]{2}{*}{ (8) “Gaming” } & Playing video-games & 0,828 \\
\hline & Playing online games & 0,421 \\
\hline
\end{tabular}

${ }^{a}$ Principal component factor analysis with varimax rotation was completed. Only factor loadings $>.40$ are listed. 


\section{References}

Antrop, I., Roeyers, H., Van Oost, P., \& Buysse, A. (2000). Stimulation Seeking and Hyperactivity in Children with ADHD. Journal of Child Psychology 41(2), 225- 231. doi: 10.1111/1469-7610.00603.

Baerg, S., Cairney, J., Hay, J., Rempel, L., Mahlberg, N., \& Faught, B.E. (2011). Evaluating physical activity using accelerometry in children at risk of developmental coordination disorder in the presence of attention deficit hyperactivity disorder. Research in developmental disabilities, 32(4),1343 - 1350. doi: 10.1016/j.ridd.2011.02.009

Bioulac, S., Lallemand, S., Fabrigoule, C., Thoumy, A.L., Philip, P., \& Bouvard., M.P. (2014). Video Game Performances Are Preserved in ADHD Children Compared With Controls. Journal of Attention Disorders, 18(6), 542-550. doi: 10.1177/1087054712443702.

Blanck, P. (2014). The struggle for web eQuality by persons with cognitive disabilities. Behavioral Sciences and the Law, 32(1), 4-32. doi: 10.1002/bsl.2101

Bolic, V., Lidström, H., Thelin, N., Kjellberg, A., \& Hemmingsson, H. (2013). Computer use in educational activities by students with ADHD. Scandinavian Journal of Occupational Therapy, 20(5), 357-364. doi: 10.3109/11038128.2012.758777

Bryce, J. (2001). The Technological Transformation of Leisure. Social Science Computer Review, 19(1), 7-16. doi: 10.1177/089443930101900102

Cardon, D., \& Granjon, F. (2005). Social networks and cultural practices. A case study of young avid screen users in France. Social Networks, 27, 301-315. doi:

10.1016/j.socnet.2004.11.005 
Carli, V., Durkee, T., Wasserman, D., Hadlaczky, G., Despalins, R.,...Kaess, M. (2013). The Association between Pathological Internet Use and Comorbid Psychopathology: A Systematic Review. Psychopathology, 46(1), 1-13. doi: 10.1159/000337971

Chan, P. A., \& Rabinowitz, T. (2006). A cross-sectional analysis of video games and attention deficit hyperactivity disorder symptoms in adolescents. Annals of General Psychiatry, 5(16), 1-10. doi: 10.1186/1744-859X-5-16

Chou, W. J., Liu, T. L., Yang, P., Yen, C. F., \& Hu, H. F. (2015). Multi-dimensional correlates of Internet addiction symptoms in adolescents with attention-deficit/hyperactivity disorder. Psychiatry Research, 225, 122-128. doi: 10.1016/j.psychres

Cox, M. J. (2013). Formal to informal learning with IT: research challenges and issues for elearning. Journal of Computer Assisted Learning 29(1), 85-105. doi: 10.1111/j.13652729.2012.00483

Douris, PC., McDonald, B., Vespi, F., Kelley, NC., \& Herman, L. (2012). Comparison between Nintendo Wii Fit aerobics and traditional aerobic exercise in sedentary young adults. Journal of Strength and Conditioning Research, 26(4), 1052-1057. doi: 10.1519/JSC.0b013e31822e5967.

Dutta-Bergman, M. J. (2004). Complementarily in consumption of news types across traditional and new media. Journal of Broadcasting and Electronic Media, 48(1), 41-60. doi: 10.1207/s15506878jobem4801_3

Engel-Yeger, B., \& Ziv-On, D. (2011). The relationship between sensory processing difficulties and leisure activity preference of children with different types of ADHD. Research in developmental disabilities, 32(3), 1154 - 1162. doi: 10.1016/j.ridd.2011.01.008 
Engelhardt, C. R, Mazurek, M. O., \& Sohl, K. (2013). Media use and sleep among boys with autism spectrum disorder, adhd, or typical development. Pediatrics, 132(6), 1081- 1089. doi: 10.1542/peds.2013-2066

Field, A. (2013). Discovering Statistics using IBM SPSS Statistics. Thousand Oaks, California: SAGE Publications Ltd.

Findahl, O. (2014). Svenskarna och internet (Swedes and the Internet). Stockholm: Internet Infrastructure Foundation. Retrieved from http://www.soi2014.se/

Gentile, D. A. (2011). The Multiple Dimensions of Video Game Effects. Child Developmental perspectives 5(2), 75-81. doi: 10.1111/j.1750-8606.2011.00159.x

Gentile, D.A., Swing E.L., Lim, C.G., \& Khoo, A. (2012). Video Game Playing, Attention Problems, and Impulsiveness: Evidence of Bidirectional Causality. Psychology of Popular Media Culture, 1(1), 62-70. doi:10.1037/a0026969

Hoza, B. (2007). Peer Functioning in Children With ADHD. Journal of Pediatric Psychology 32(6), 655-663. doi: 10.1093/jpepsy/jsm024

Johnson, R. C., \& Rosén, L. A. (2000). Sports behavior of ADHD children. Journal of Attention Disorders 4(3), 150- 160. doi: 10.1177/108705470000400302

King, G., Law, M., King, S., Rosenbaum, P., Kertoy, M., \& Young, N. (2003). A conceptual model of the factors affecting the recreation and leisure participation of children with disabilities. Physical \& Occupational Therapy in Pediatrics 23(1), 63-90. doi: 10.1080/J006v23n01_05

Kopp, S. (2010). Girls with Social and/or Attention Impairments (Doctoral Dissertation, Institute of Neuroscience and Physiology Child and Adolescent Psychiatry, University of 
Gothenburg, Sweden). Retrieved from

https://gupea.ub.gu.se/bitstream/2077/23134/1/gupea_2077_23134_1.pdf

Law, M. (2002). Participation in the Occupations of Everyday Life. American Journal of Occupational Therapy 56, 640-649. doi: 10.5014/ajot.56.6.640

Law, M., Petrenchik, T., Ziviani, J., \& King, G. (2006). Participation of children in school and community. In S. Roger \& J. Ziviani (Eds.), Occupational therapy with children: understanding children`s occupation and enabling participation (pp.67-90). Oxford, UK: Blackwell Publishing Ltd.

Lidström, H. (2011). ICT and participation in school and outside of school activities for children and students with physical disabilities (Doctoral Dissertation, Department of Neurobiology, Care Sciences and Society Division of Occupational Therapy, Stockholm University, Sweden). Retrieved from https://publications.ki.se/xmlui/bitstream/handle/10616/40571/Thesis_Lidstrom.pdf?sequence $=1$

Lidström, H., Ahlsten, G., \& Hemmingsson, H. (2010). The influence of ICT on the activity patterns of children with physical disabilities outside school. Child: care, health and development, 37(3), 313-321. doi: 10.1111/j.1365-2214.2010.01168.x

Lidström, H., Granlund, M., \& Hemmingsson, H. (2012). Use of ICT in school: A comparison between students with and without physical disabilities. European Journal of Special Needs Education, 27, 21-34. doi: 10.1080/08856257.2011.613601

Lin, C. Y., Yang, A.L., \& Su, C.T. (2013). Objective measurement of weekly physical activity and sensory modulation problems in children with attention deficit hyperactivity 
disorder. Research in developmental disabilities, 34(10), 3477- 3486. doi:

10.1016/j.ridd.2013.07.021

Livingstone, S., Haddon, L., Görzig, A., \& Ólafsson, K. (2011). Risks and safety on the internet: The perspective of European children. Full Findings. LSE, London: EU Kids Online. Retrieved from http://eprints.1se.ac.uk/33731/1/Risks\%20and\%20safety\%20on\%20the\%20internet $\% 281$ sero\% 29.pdf

Livingstone, S., \& Brake, D.R. (2010). On the rapid rise of social networking sites: new findings and policy implications. Children \& society, 24(1), 75-83. doi: 10.1111/j.10990860.2009.00243.x

Moriyama, TS., Polanczyk, G., Caye, A., Banaschewski, T., Brandeis, D., \& Rohde, LA. (2012). Evidence-based information on the clinical use of neurofeedback for ADHD. Neurotherapeutics 9(3),588-98. doi: 10.1007/s13311-012-0136-7.

McQuade, J.D., \& Hoza, B. (2008). Peer Problems in attention deficit hyper activity disorder: current status and future directions. Developmental disabilities research reviews 14, 320 324. doi: $10.1002 /$ ddrr.35

Mishra, J., Merzenich., M.M \& Sagar, R.

Accessible online neuroplasticity-targeted training for children with ADHD 
Nguyen, A., \& Western, M. (2006). The complementary relationship between the Internet and traditional mass media: The case of online news and information. Information Research-an International Electronic Journal, 11(3), 151-183. Retrieved from Scopus database.

Primeau, L.A. (1996). Work and Leisure: Transcending the Dichotomy. The American Journal of Occupational Therapy, 50(7), 569- 577. doi: 10.5014/ajot.50.7.569

Polit, D.F., \& Beck, C.T. (2008). Nursing research. Generating and assessing evidence for nursing research. Baltimore, MD: Lippincott Williams \& Wilkins.

Rideout, V. J., Foehr, U. G., \& Roberts, D.F. (2010). Generation M2. Media in the Lives of 8to 18-Year-Olds. Menlo Park, California: A Kaiser Family Foundation Study. Retrieved from https://kaiserfamilyfoundation.files.wordpress.com/2013/04/8010.pdf

Schreuer, N. (2014). Accessibility to Information and Communications Technology for the Social Participation of Youths with Disabilities: A Two-way Street: Accessibility to ICT for youths with disabilities. Behavioral Sciences \& The Law 32(1), 76-93. doi: 10.1002/bsl.2104

Shaw, L., \& Gant, L.M. (2002). In Defense of the Internet: The Relationship between Internet Communication and Depression, Loneliness, Self-Esteem, and Perceived Social Support. Cyberpsychology \& Behaviour 5(2), 157-171. doi:10.1089/109493102753770552

Shimoni, M., Engel-Yeger, B., \& Tirosh, E. (2010). Participation in leisure activities among boys with attention deficit hyperactivity disorder. Research in Developmental Disabilities 31(6), 1234-1239. doi: 10.1016/j.ridd.2010.07.022

Sonuga-Barke, E.J.S. (2002). Psychological heterogeneity in AD/HD — a dual pathway model of behaviour and cognition. Behavioural Brain Research 130(1), 29-36. doi: 10.1016/S01664328(01)00432-6. 
Subrahmanyama, K., Greenfield, P., Krautc, R., \& Gross, E. (2001). The impact of computer use on children's and adolescents' development. Applied Developmental Psychology, 22, 7-30.

Suto, M. (1998). Leisure in Occupational Therapy. Canadian Journal of Occupational Therapy 65(5), 271- 278. doi: 10.1177/000841749806500504

The Swedish Media Council. (2005). Ungar \& Medier: Fakta om barns och ungas användning och upplevelser av medier (Kids \& Media: Facts about children' and youth' use and experience of media). Stockholm: Kultur- och Utbildningsdepartementet. Retrieved from the Swedish Media Council website:

http://www.statensmedierad.se/upload/Rapporter_pdf/Ungar_\&_Medier_2005.pdf

The Swedish Media Council. (2006). Ungar \& Medier: Fakta om barns och ungas användning och upplevelser av medier (Kids \& Media: Facts about children and youth' use and experience of media). Stockholm: Kultur- och Utbildningsdepartementet. Retrieved from the Swedish Media Council website:

http://www.statensmedierad.se/upload/Rapporter_pdf/Ungar_\&_Medier_2006.pdf

Thompson, D., \& Emira, M. (2011). 'They say every child matters, but they don't': an investigation into parental and carer perceptions of access to leisure facilities and respite care for children and young people with Autistic Spectrum Disorder (ASD) or Attention Deficit, Hyperactivity Disorder (ADHD). Disability \& Society, 26(1), 65-78. doi:

$10.1080 / 09687599.2011 .529667$

Vandebosch, H, (2011). eYouth : Balancing between Opportunities and Risks. Bruxelles, BEL: Peter Lang AG. 
Voogt, J., Knezek, G., Cox, M., Knezek, D \& ten Brummelhuis, A. (2011). Under which conditions does ICT have a positive effect on teaching and learning? A Call to Action. Journal of Computer Assisted Learning , 29(1), 4-14. doi: 10.1111/j.1365-2729.2011.00453.x Yelland, N \& Neal, G. (2013). Aligning digital and social inclusion: A study of disadvantaged students and computer access. Education and Information Technologies 18(2), 133-149. doi: 10.1007/s10639-012-9223-y

Yen, J.Y., Yen, C.F., Chen, C. S., Tang, T.C., \& Ko, C.H. (2009). The association between adult ADHD symptoms and internet addiction among college students: The gender difference. Cyberpsychology and Behavior, 12(2), 187- 191. doi: 10.1089/cpb.2008.0113.

Yen, C.F., Chou, W.J., Liu, T.L., Yang, P. Hu, H.F. (2014). The association of Internet addiction symptoms with anxiety, depression and self-esteem among adolescents with attention-deficit/hyperactivity disorder. Comprehensive Psychiatry, 55(7), 1601-1608. doi: 10.1016/j.comppsych.2014.05.025.

Weiss, M., Baer, S., Allan, B. A., Saran, K., \& Schibuk, H. (2011). The screens culture: impact on ADHD. ADHD Attention Deficit And Hyperactivity Disorders, 3(4), 327-334. doi: $10.1007 / \mathrm{s} 12402-011-0065-\mathrm{Z}$ 